\title{
HISTORIC TRAIL MAPS OF THE RATON AND SPRINGER 30' x 60' QUADRANGLES, NEW MEXICO AND COLORADO
}

\author{
By Glenn R. Scott
}

\begin{abstract}
The earliest human occupation of the Raton-Springer area was by Folsom man whose artifacts were found at a site near Folsom in the eastern part of the Raton quadrangle. Succeeding cultures probably included people who made paralle!-flaked points about 7,000 years ago, Archaic culture about 5,500 years ago, Woodland culture about 1,500-1,000 years ago, and the slightly later Panhandle culture. The later Indian tribes occupying the area included the Plains Apache, Ute, and Comanche.

The earliest white entry in the Raton-Springer area was the Spanish Coronado expedition of 1541 (fig. 1). The Spaniards later sent missionaries and colonized part of the area, known as New Spain, with variable success. After several successful revolts by the Pueblo Indians, the Spaniards instituted rule of the area until September 27. 1821 when Mexico became independent. During the Spanish domination, military expeditions periodically traveled through the area to maintain peace with the Indians, fend off intrusion by the French, explore potential mineral deposits, and encourage trade with the Indians.

Immediately after independence, Mexico opened up her markets to trade with the outside world, especially the United States. Gold, silver, furs, and other commodities brought back to the states produced a lucrative trade. Some Americans established citizenship in Mexico and obtained land grants in New Spain. In the early 1840's. tension mounted between the United States and Mexico over settlers in Texas and on May 13, 1846, President Polk announced war with Mexico. General Stephen W. Kearny, commander of the Army of the West, marched into Santa Fe on August 18, 1846 without a shot being fired, and declared the area to be part of the United States. The Treaty of Guadalupe Hidalgo, signed February 2, 1848, confirmed the new ownership and established boundaries. Most of the Spanish land-grant titles were ultimately confirmed. In 1850, the Territory of New Mexico was established, further opening the area to trade and settlement.

Settlement by white people was slow in coming to this area, mainly because of tension between the whites and the various Indian tribes. Marauding Indians made life hazardous for travelers and effectively prevented settlement, except for large groups of Indian-wise settlers such as those who lived in Cimarron. By the 1870's most of the Indians were living on reservations and permanent settlement by the whites began. The Santa Fe Trail was an important influence, bringing trade and settlers into the area from 1821 until 1878. The earliest settlements were along the trail, and by the middle 1840's trade reached nearly one half a million dollars per year.
\end{abstract}

The Santa Fe Trail (fig. 2) is the principal subject of the Raton-Springer historic trail maps; therefore, the methods of locating the trails and constructing the maps are discussed here. In the surveyed areas the trail was plotted by the General Land Office surveyors. Although it was plotted fairly accurately, the accuracy was not comparable to that gained by using aerial photographs. Therefore, with a stereoscope, the photographs were searched for the trail which was then traced with a colored pencil. The trail alinement was then plotted photogrammetrically onto the final maps. The main branches of the trail show plainly on aerial photos and on the ground in all areas except where obliterated along streams or in cities such as Raton. Lessused trails that were not part of the Santa Fe Trail system were less visible and many could not be drawn continuously to their destinations. Railroad alinements were drawn by the same method. Ghost towns were difficult to relocate and some probably are not accurately placed. The chronology starts when the first white men entered the area and ends after the last known stage line.

\section{CHRONOLOGY OF SOME HISTORICAL EVENTS IN THE RATON AND SPRINGER QUADRANGLES} 1541

Francisco Vasquez de Coronado possibly traveled across the southeastern part of present Colfax County, New Mexico.

1696

Governor Don Diego de Vargas went to El Cuartelejo through the present Springer quadrangle to recapture some Taos and Picuris Indians, but route is unknown.

1706

Juan de Ulibarri, 40 Spanish soldiers, and 100 Indian allies came through Cimarron area on their way north to recapture Picuris Indians from the Apaches. He first encountered the Jicarilla Apache Indians near present Cimarron, New Mexico.

1715

General Juan Paez Hurtado visited area southeast of present Cimarron.

1719

Don Antonio de Valverde visited the Jicarilla Apache Indians near present Cimarron, then traveled northeastward through present Colorado and into Kansas.

1720

Pedro de Villasur led 40 soldiers and 60 Indian allies through the map area on an expedition to learn 
whether the French were operating in Spanish Territory. The party was attacked by Pawnee Indians and French near the North Platte River and only 13 spanish soldiers escaped.

1724

Don Juan Domingo de Bustamante visited the present Cimarron area to find a site for a Spanish fort and Apache settlement.

1727

Bustamante visited the area again but no fort or settlement was ever built as a result of his visits.

1739

The Mallet brothers and a group of French Canadian fur traders came through area from the north on their way to Santa Fe, New Mexico.

$1812-1840$

Trappers in the area included Charles Beaubien, Charles and William Bent, Thomas Boggs, Kit Carson, August P. Chouteau, Jules DeMunn, Robert Fisher, Tim Goodale, John Hawken, Matthew Kinkead, Maurice Le Duc, Antoine Leroux, Lucien Maxwell, Bill New, James O. Pattie, Joseph Philibert, Antoine Robidoux, Ceran St Vrain, George Simpson, Bill Williams, Dick Wootton,

1812 and Ewing Young.

James Baird and 12 other men went through the Raton area on way to Santa Fe.

1814

Joseph Philibert trapping party was in northern New Mexico.

1815

Auguste P. Chouteau and Jules de Munn went through area on way to Taos and Santa Fe.

1821

William Becknell led first trading expedition to Santa Fe and in 1822 opened up the Cimarron Cutoff of the Santa Fe Trail to wagon transport. Also, Jacob Fowler and party went northeastward through area when returning from a beaver trapping trip to the Rocky Mountains.

1823

Baird Chambers trading party traveled through the area.

1825

Major part of the Santa Fe Trail (Cimarron Cutoff) surveyed by the Santa Fe Road Commission (Joseph C. Brown, surveyor). Approximate route of survey in map area shown by Riddle (1963).

NAMES OF CAMPING STOPS ALONG THE CIMARRON CUTOFF, SANTA FE TRAIL

1. Wagon Mound at Santa Clara Spring.

2. Crossing of Ocate Creek.

3. Rock Crossing of the Canadian River (Rio Colorado or Red River)

4. Jaritas (same as Chico?)

5. Chico (same as Point of Rocks?).

6. Point of Rocks.

7. El Rito Palo Blanco (east of map area).

8. Whetstone Creek or Grindstone Creek-Piedra de Amolar (east of map area)

In a later year, Francis Xavier Aubrey used a new wagon trail over Manco Burro Pass, through Trinchera, past Two
Buttes, and to the Rio Napesta (Arkansas River). This was not Aubrey's new eastern trail, which was east of the map area.

1831-1840

Dr. Josiah Gregg, a physician, made several trips to Santa $\mathrm{Fe}$ and later wrote "Commerce of the Prairies" (1845), a description of his travels.

\section{1}

Charles Hypolite Beaubien and Guadalupe Miranda received a grant of land from the Mexican Governor, Manuel Armijo. In 1843 Beaubien and Charles Bent began to settle the part of the grant where Ponil Creek leaves the mountains northeast of Cimarron. When the northern part of Mexico was taken over by the United States, the validity of all land grants was evaluated. The Beaubien and Miranda (Maxwell) land grant was validated and the size of the approved area was much larger than the grantees had asked for. The Beaubien and Miranda grant was probably the largest individual real estate holding in the history of the United States.

1843

A wagon train returning east from Santa Fe crossed Raton Pass on Mountain Branch for the first time. Apparently about this time Mexican soldiers escorted caravans from Rock Crossing at Franklin to Santa $\mathrm{Fe}$

1844

Kit Carson, Dick Owens, Tom Boggs, and John Hatcher settled on Ponil Creek

1845 and 1846

Lt. James William Abert and Lt. W. G. Peck, conducted exploratory expeditions to the Purgatoire River area of Colorado and the northeastern part of New Mexico along the route of the Mountain Branch of the Santa Fe Trail. In 1845 he started crossing Raton Pass on Aug. 23, reached the top on Aug. 24, went down the Canadian River and left the area on Aug. 28. In 1846 he arrived at Bents Fort on Juiy 30 and was forced to stay there until Sept. 9 because of illness. On Sept. 16, he started crossing Raton Pass, reached Willow Spring on Sept. 19, and left the area on Sept. 22. He described the natural history of the regions.

1846-1850

Mail between Fort Leavenworth and Santa Fe was delivered under separate trip contracts let by the U.S. Quartermaster's Department.

1846

Brigadier General Alexander W. Doniphan's expedition passed through future site of Raton. With him was Reuben (Pap) Letton who selected Willow Spring as future site of a U.S. Forage Station. The site was later the townsite of Raton. Mormon Battalion, 525 male members of the Church of the Latter Day Saints who joined the army to earn money to support the movement of church members to Utah, came through area on Cimarron Cutoff in September 1846 and followed the Santa Fe Trail to Santa Fe.

1846 August

Lt. William Hemsley Emory passed through the area 
with the advanced guard of Col. Kearny's Army of the West with Tom Fitzpatrick as guide. He started across Raton Pass with wagons on Aug. 6 and reached the pass and Willow Spring Aug. 7. Many of his wagons were broken during the crossing. He left the Springer quadrangle on Aug. 11. He described and collected plants during his exploration.

1846 August

Colonel Stephen Watts Kearny camped at Willow Spring after crossing Raton Pass on his way to Santa Fe to take over the northern part of Mexico for the United States. He commanded 1,750 1847 mounted dragoons (cavalrymen)

Antagonism against the Americans by the Indians and Mexicans made travel on the Cimarron Cutoff of the Santa Fe Trail extremely hazardous.

1847 March 3

Congress declared the trail from Independence, Missouri via Bents Fort to Santa $\mathrm{Fe}$ a post route.

1848

Charles Beaubien brought supplies and men from Taos to start a permanent settlement at Rayado.

1848 June 19

Fourteen persons, including Lucien Maxwell, Charles Town, Peter Joseph, Elliott Lee, Indian George, and two children, were attacked by about 150 Jicarilla Apache Indians in Manco Burro Pass and several of the party were killed or wounded. Apparently nine men and two children survived.

1849 April

Kit Carson came to Rayado.

1849 (pre-Oct.)

Lt. John Whittlesey ordered Sgt. Williams, 15 dragoons. and 30 volunteers to guard the settlement at Rayado.

1849 October

A party enroute to Missouri with 13 wagons was ambushed by Apache Indians west of Point of Rocks on the Cimarron Cutoff. A man named White and twelve other men were killed; Mrs. White, her child, and a negro nurse were captured. Mrs. White later was killed and the child and nurse disappeared. Indian attacks continued through the mid-1850's.

1850 May 24

Orders were issued to start an Army post at Rayado. The post was garrisoned by 43 men of Companies $G$ and I, First Dragoons, under Capt. William S. Grier. Ten mounted dragoons under Sgt. William C. Holbrook had been temporarily stationed at 1850 Rayado since the fall of 1849 .

Cimarron Cutoff mail route was used 1850-1861. Monthly mail service contract from the Post Office Department was awarded to Dr. David Waldo of Waldo, Hall \& Co. for service between Independence, Missouri and Santa Fe, New Mexico along the Cimarron Cutoff. Light carryall Dearborn or Jersey wagons probably were used; passenger service including meals cost $\$ 150$. Thirty days were allowed for each trip and the mail went through Wagon Mound. Mules generally were used to pull the wagons. Passengers slept on the ground during the 25-30 days required for the trip. Capacity was 9 passengers inside and 2 on top. Some wagons were escorted by an army patrol. A mail express carrying mail from Fort Leavenworth to Santa Fe was attacked by Jicarilla Apache and Mohuache Ute Indians in May 1850 and all messengers were killed near Santa Clara Spring, which is in the canyon northwest of present Wagon Mound. At a later time the Sim Calley Ranch at Santa Clara Spring was being used as a stage station. Earlier, a Mexican Custom House was said to be at present Wagon Mound (Long, 1947, p. 252).

1851 August 31

The garrison at Post Rayado was reduced to one noncommissioned officer and 14 privates; construction of Fort Union was started. Soon after the Fort was occupied, soldiers were dispatched to the bottomland of Ocaté Creek to grow vegetables.

\section{September 26}

Fort Union Post Office opened, and mail stages traversed a military road (Wagon Mound-Fort Union Cutoff) from the Canadian River crossing southwestward around the north side of the Turkey Mountains to Fort Union.

1854

Kit Carson was appointed Indian agent for northern New Mexico.

1854

Horn Cabin built at crossing of the Mountain Branch of the Santa Fe Trail and Crow Creek; used by travelers and later became a stage station.

1854

Congress awarded Jacob Hall a 4-year contract to start July, 1, 1854 for monthly service each way from Independence to Santa Fe in 6-mule stagecoaches, each trip to take 25 or less days. The company name Hockaday and Hall was used.

1854 July 16

Lt. J. W. Davidson established temporary camp at Rayado with 61 men from the First Dragoons. Troops left in mid-September.

1855 September

Army campaigns against the Ute and Apache Indians finally led to a formal peace treaty, but the Indian raids continued.

1857 July 1

Hockaday \& Hall's contract was renegotiated and semi-monthly mail service from Independence to Santa Fe was begun over the Cimarron Cutoff.

1857 or 1858

Lucien Maxwell began to move his residence and ranch to the site of present day Cimarron.

1858 March

Capt. Randolph Barnes Marcy, U.S. Army, picked up horses and mules at Rayado and went north through area to deliver the stock in Utah.

1858 July 1

Jacob Hall received another 4-year contract and as 
Hall \& Porter, started weekly mail service over the Cimarron Cutoff.

1859 November

Hall and Porter was the first regular mail stage company to use the Mountain Branch over Raton Pass.

1859 and 1860

Capt. J. N. Macomb's exploring expedition followed the Cimarron Cutoff across the Rock Crossing to Fort Union. With him was John Strong Newberry, M. D., who described the geology and collected fossils along the Cimarron Cutoff of the Santa Fe Trail.

1859 and 1860

Travel became almost impossible because of attacks by the Comanche and Kiowa Indians along the Santa Fe Trail.

1860

Majors, Waddell, \& Russell Freight Company generally hauled along the Cimarron Cutoff in the summer and along the Mountain or Bents Fort Branch over Raton Pass in the winter until 1860 , when they were caught in Raton Pass in a snowstorm and had to build cabins and camp there until spring. Dick Wootton later built his tollgate at the cabin site.

1860

Willow Spring U.S. Forage Station was established in the 1860's on the west bank of Willow Creek (later Raton Creek) just opposite point of Soldier Hill in the northern part of Raton. Willow Spring was later used by the Barlow, Sanderson \& Co. Stage Line as a water stop.

1861

A reservation was established at Cimarron for the Ute and Jicarilla Apache Indian Tribes. Occasionally 1861 Lucien Maxwell acted for the Indian Agent.

An independent pony express from Denver to Santa Fe was established over the old Taos Trail which went down the Rio Grande west of this area. but lasted only one year.

1861 January 1

Missouri Stage Co., successor to Hall and Porter, carried mail on the Mountain Branch, starting in February 1861. The Cimarron Cutoff was abandoned as a mail route and a post office was established ai Cimarron.

1861 May

Slemmons. Roberts \& Co., took over mail delivery on the Mountain Branch. Line was called the Kansas City, Santa Fe and Canon City Fast Line.

1862

First Regiment of Colorado Volunteers under Col. John P. Slough, with Lt. Col. S. F. Tappan, and Major John M. Chivington, went southward from Raton Pass through area on way to victorious engagement with the Confederate Army under Gen. H. H. Sibley at Glorieta Pass.

1862 July 1

Cottrill, Vickroy \& Co. carried mail on the Mountain Branch from Bents Fort, sometimes under the name Southern Mail Co.
1863 March

M. Cottrill \& Co., owned by Cottrill, Barlow, and Barnum carried mail from Kansas City to Santa Fe.

1865 January 21

Santa Fe Stage Co.. in part run by J. P. Sanderson, took over the delivery of mail to Santa Fe.

1865

Richens Lacy Wootton built a 27-mile toll road over Raton Pass with a tollgate just north of the Colorado State line. The Colorado Territorial Legislature passed an act to incorporate the Trinidad and Raton Mountain Wagon Road Company on Feb. 20, 1865. Until Wootton built the road, the route across the pass had been in very bad condition and it took 5 days to travel the 27 miles. The road made 18 steep crossings of Raton Creek.

1866

Barlow \& Sanderson's Southern Overland Mail \& Express $C o$. received the mail contract and started running stage service between Kansas City \& Santa $\mathrm{Fe}$ on a weekly schedule. Home and swing stations were built and the trip took 13 days. The following stage stops along the Mountain Branch were made in the Raton and Springer areas:

1. Willow Spring-water stop and emergency station.

2. Clifton House (Stockton Station, Red River Station)-home station (where the passengers got food and lodging for the night), corrals, and blacksmith shop.

3. Crow Creek-swing station (where the stock tenders changed the horses).

4. Vermejo-swing station.

5. Cimarron-home station, stables.

6. Rayado-swing station.

7. Sweetwater-swing station.

8. Calhouns Crossing-swing (?) station, a 7-room hotel lay on west side of Mountain Branch of the Santa Fe Trail on south side of Ocaté Creek near present Calhoun Cemetery. Wild Bill Hickok reportedly drove a stage coach over Raton Pass for Barlow, Sanderson \& Co. The company ran stages from the end of track as the railroad was extended westward. In 1872, the firm's name was changed to Barlow and Sanderson Co. The freighting business also was forced to gradually move westward from the end of track. After the Atchison, Topeka. \& Santa Fe Railroad reached the east end of the Cimarron Cutoff in western Kansas in 1872, the cutoff was no longer used and the Aubrey Route or the Mountain Branch was used. Probably about this same time(?) Mathias Heck opened a stage station and store at the crossing of Sweetwater Creek on the Mountain Branch south of Rayado.

1866

Charles Goodnight moved cattle over Raton Pass once, but then used Trinchera Pass because of the high toll charged by Wootton. Goodnight and Oliver Loving established the Goodnight-Loving Cattle Trail from the Pecos River to Cheyenne. Wyo. 
1866

Copper was discovered on Baldy Mountain west of the map area.

1866-1867

A military post was garrisoned by troops under Lt. George Campbell at Maxwell's ranch at Cimarron to keep the peace at the Indian Agency.

1867

Gold was discovered on Baldy Mountain. 1867

Trinchera Pass was first used by wagons.

The United States and Mexico Telegraph Co. Denver to Santa Fe, was authorized. In 1868 the telegraph line was built across the map area.

1867

Denver \& Santa Fe Stage Line (owned by Abraham Jacobs and Jones) operated between Denver and Trinidad until the fall of 1869 .

1867

Beginning in the fall of 1867, Barlow, Sanderson and Co. ran stages from Hays City, Kansas to Santa Fe.

1868

Smith A. Sayre established Willow Spring Ranch, which included a store, telegraph office for the newly installed line, a room or two for guests, and a corral.

1868 March 2

Articles of Incorporation of the Trinidad and Moreno Valley Wagon Road were completed, after which stages ran from Trinidad to Elizabethtown and Virginia City across the northwestem part of the Raton quadrangle.

\section{Early}

V. S. Shelby Stage Line inaugurated triweekly runs between the Maxwell Ranch at Cimarron and Elizabethtown. Daily service started July 1. Fare was $\$ 8.00$. Carried passengers and gold. Elizabethtown started to dwindle in 1870 and was deserted by $1875 . \mathrm{H}$. H. Hankins ran a livery and stage line based at Elizabethtown. The stagecoach ran between Springer and Elizabethtown during the boom time. Another stage line ran from Maxwell to Ute Park.

1869 January 25

Colfax County was created, named for Schuyler Colfax, Vice President of the United States.

1869 February 11

The Las Animas City and Fort Union Wagon Road Co. was formed. It was to start at head of Purgatoire Canyon, go through Vega Redondo and Sugarite Canyon, bypassing Trinidad and Raton Pass.

1869

Barlow, Sanderson \& Co.. ran a connecting stage line from Denver, Pueblo, and Trinidad. In June 1869 , Southem Overland Mail Co. started triweekly service to Santa Fe.

1870 April 30

Lucien Maxwell sold the Beaubien and Miranda land grant to an English syndicate.
1870 July 1

Abraham Jacobs sold his Denver and Santa Fe Stage 1876

Line to Barlow, Sanderson \& Co.

A geological atlas of the northeastern part of New Mexico was published by the Wheeler Survey. The Wheeler Survey, supervised by Lt. George M. Wheeler, was one of the four topographical and geological surveys of western United States during the 1860's and 1870's. The areas mapped included parts of California, Nevada, Arizona. New Mexico, and Utah.

1876 May

Trinidad was the northern terminus of the Barlow and Sanderson Co. Stage Line from Trinidad to Santa Fe.

1876 September

The Cimarron Indian Reservation was closed. 1878

J. L. Sanderson \& Co. Stage Line took over from Barlow and Sanderson Co.

1879 January

Atchison, Topeka, and Santa Fe Railroad reached Raton from Trinidad. The first locomotive came over Raton Pass on Dec. 7, 1878. Use of the Mountain Branch of the Santa Fe Trail greatly decreased. On July 7, 1879 a tunnel was completed under the pass.

1879 June

Hopper Bros. Stage Line carried passengers to Las Vegas from Otero for $\$ 10.00$. Round trip was $\$ 15.00$.

1880 January 24

Barlow and Sanderson closed down its stage and mail operation to Santa Fe shortly before the railroad reached there on February 9, 1880.

1890 April 1

Union Pacific Denver \& Gulf Railway filed incorpora. tion papers at Folsom. The Catskill Branch was constructed.

1893 October 12

U.P.D. \& G. went into receivership, but then continued to operate the Catskill Branch until 1898.

1894 April 7

Springer and Moreno Valley Stage Co., Incorporated; started operating May 6. Daily service from Springer to Cimarron, Ute Creek, Baldy, Perryville, and Elizabethtown.

1896

Moreno Valley Stage and Freight Co. owned by H. H. Hankins was operating.

1896 July 24

Floods destroyed 12 miles of the Catskill Branch of the U.P.D. \& G.

1905 February 25

St. Louis, Rocky Mountain \& Pacific R.R. started. 1907

A. P. Whiteley stage ran from Maxwell City to Dawson. 1910 (?)-1914

George A. Honeyfield operated a hack from Raton to Blossburg and Brilliant. 
Table 1.- Miles between stations along the Cimarron Cutoff and aggregate miles from Independence, Missouri.

\begin{tabular}{|c|c|c|c|c|c|c|}
\hline \multicolumn{7}{|c|}{$[---$, no data. $]$} \\
\hline & \multicolumn{2}{|c|}{$\begin{array}{c}\text { Brown, } 1933 \\
\text { Federal } \\
\text { Survey }\end{array}$} & \multicolumn{2}{|c|}{ Gregg. 1845} & \multicolumn{2}{|c|}{ Wislizenus, 1912} \\
\hline & $\begin{array}{c}\text { Miles } \\
\text { between } \\
\text { stations }\end{array}$ & $\begin{array}{l}\text { Aggregate } \\
\text { miles }\end{array}$ & $\begin{array}{c}\text { Miles } \\
\text { between } \\
\text { stations }\end{array}$ & $\begin{array}{l}\text { Aggregate } \\
\text { miles }\end{array}$ & $\begin{array}{c}\text { Miles } \\
\text { between } \\
\text { stations }\end{array}$ & $\begin{array}{l}\text { Aggregate } \\
\text { miles }\end{array}$ \\
\hline Rock Creek & -- & -- & 8 & 591 & 20 & 581 \\
\hline $\begin{array}{l}\text { Point of Rocks } \\
\text { Rock Crossing }\end{array}$ & 31 & 659 & 19 & 610 & 20 & 601 \\
\hline $\begin{array}{l}\text { of Canadian } \\
\text { River }\end{array}$ & 17 & 676 & 20 & 630 & 20 & 621 \\
\hline $\begin{array}{l}\text { Ocaté Creek } \\
\text { Santa Clara }\end{array}$ & 6 & 682 & 6 & 636 & 6 & 627 \\
\hline Spring & -- & -- & 21 & 657 & 24 & 651 \\
\hline Rio Mora & --- & --- & 22 & 679 & $\ldots$ & --- \\
\hline
\end{tabular}

LIST OF RAILROADS AND ABBREVIATIONS USED IN THE RATON AND SPRINGER QUADRANGLES

AT\&SF

$C \& N$

C\&S

CT\&LC

Atchison, Topeka, and Santa Fe. 1878present.

Cimarron and Northwestern Railway Co. (subsidiary of CT\&LC) 1908-1930

Colorado and Southern Railway Co. (Catskill Branch) 1898-1902.

Continental Tie and Lumber Co. 19111930.

Dawson Railway Co.(EP\&SW system from 1905) 1903-1908.

DT\&FW Denver, Texas and Fort Worth Railroad Co. 1890. (Catskill Br.-became UPD\&G)

E\&SF Elkhart \& Santa Fe (Construction Co. to Farley-AT\&SF system) 1931.

EP\&SW El Paso and Southwestern Railroad Co. (Dawson Branch and Roy Branch-sold to Southern Pacific) 1905-1924.

NM? The New Mexican Railroad Co. (Blossburg Branch-AT\&SF system) 1882-1899.

NM\&SP New Mexico and Southern Pacific Railroad Co. (AT\&SF system) 1878-1899.

RM\&SF Rocky Mountain and Santa Fe Railway (leased to AT\&SF for most of this time) 1915-1942.

SFL\&E Santa Fe Liberal and Englewood Railroad Co. least of area-leased SFR\&DM 1906-?)

SFR\&DM Santa Fe, Raton and Des Moines Railroad 1907-1912? (unused after 1912).

SFR\&E Santa Fe, Raton and Eastern Railroad (sold to RM\&SF) 1906-1924.

SLC\&E St. Louis Construction \& Equipment Co. (construction company for SLRM\&P) 1905-1907.

SLRM\&P Co. St. Louis, Rocky Mountain and Pacific Co. 1905-1927 (Swastika-Brilliant, sold to AT\&SF)

SLRM\&P St. Louis, Rocky Mountain and Pacific Railway (renamed RM\&SF) 1906-1915.
UPD\&G

(3 1/2 miles of track in Dawson area).

Union Pacific, Denver, and Gulf Railway (Catskill Branch-became C\&S) 18901898.

\section{RAILROADS PROPOSED IN RATON AND SPRINGER} QUADRANGLES BUT NEVER BUILT

Arkansas Valley and Cimarron Railroad

Atlantic and Pacific RR (Did build from Isleta to Gallup. etc.).

Cimarron and Rio Grande Railroad

Cimarron and Denver Railroad

Cimarron River and Taos Valley Railroad

New Mexico \& Pacific Railroad

North and South Railway Company incorporated 1871.

Rocky Mountain and Pacific Railway

SOME HISTORIC SITES IN THE OLD PART OF

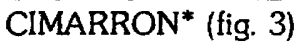

1. Early trading post. Location of Lucien B. Maxwell commissary. General store of Henry Miller Porter and Asa F. Middaugh in 1873; later, Post Office. In the early years, the building extended the entire length of the public square. In 1875 or 1878 it was the Cimarron News and Press newspaper office and in the 1890's it was the Porter and Hunt store.

2. Graves of Pabla (Paula) Lobato Beaubien, mother-inlaw of Lucien Maxwell, and Verenisa Maxwell, little daughter of Lucien Maxwell, 1864.

3. Plaza well, dug about 1871 and used by freighters hauling from Kansas Territory to Fort Union. Overnight campground and watering place for horses and oxen.

4. Site of Lucien B. Maxwell home, built in 1857-1858? by Jack (John?) Holland?

5. Building renovated in 1871 as a home for the Henry Tinson family and later served as the National Hotel.

6. Old home believed to have been the office of the Cimarron News about 1872.

7. St. James Hotel, started by Henry Lambert in 1872 , completed in 1882.

8. The Adobe, built before 1892 ?

9. The second Colfax County Court House, 1870.

10. Aztec Grist Mill, built in 1864 for Lucien B. Maxwell by James Truax, stone mason, to grind wheat into flour for soldiers at Ft. Union. Mill was used to issue rations to Moache Ute and Jicarilla Apache Indians. Estimated annual profit was $\$ 26,440$. Now converted to museum by the owners, Mr. and Mrs. J. Les Davis of the CS Ranch.

11. Tom Boggs home in 1865; he was mountain man and companion of Kit Carson. The Boggs were foster parents to the Kit Carson children.

12. Immaculate Conception Catholic Church, built 18811884 ?

13. Schwenk Hall.

14. Juan Charette's saloon. Barlow and Sanderson stageline office apparently was at the location of the saloon. and the stage stopped across the street west of Schwenk Hall?

15. Colfax County jail 1872

*Information from Marilyn Mullins, Springer News Bulletin Editor, Feb. 18, 1983, and from Frank Alpers, historian, Raton, March 1983. 


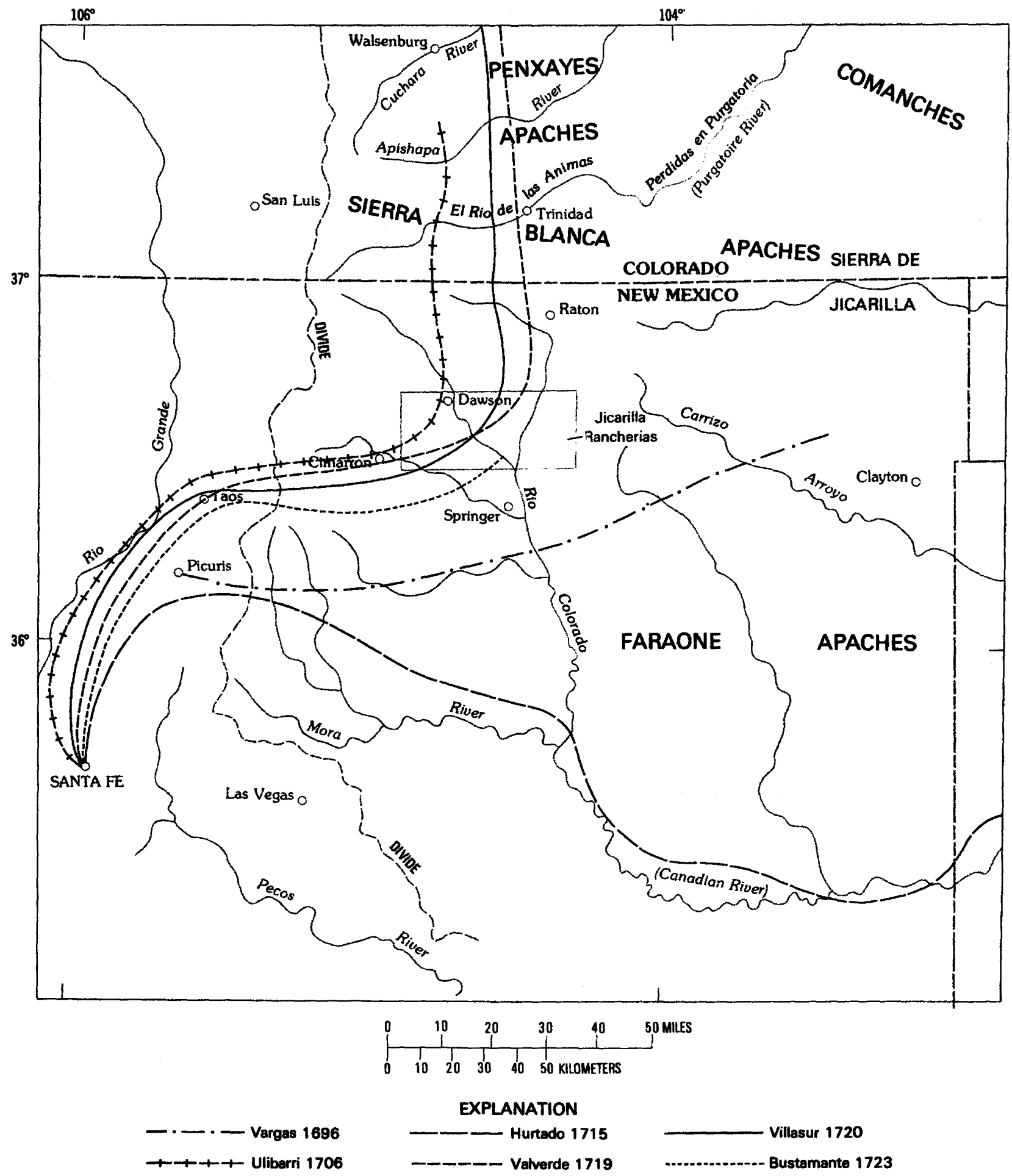

Figure 1.-Map showing routes of Spanish exploration northeast of Santa Fe, New Mexico, 1696-1727

(Compiled from the Spanish Archives by Alfred B. Thomas, 1935) 


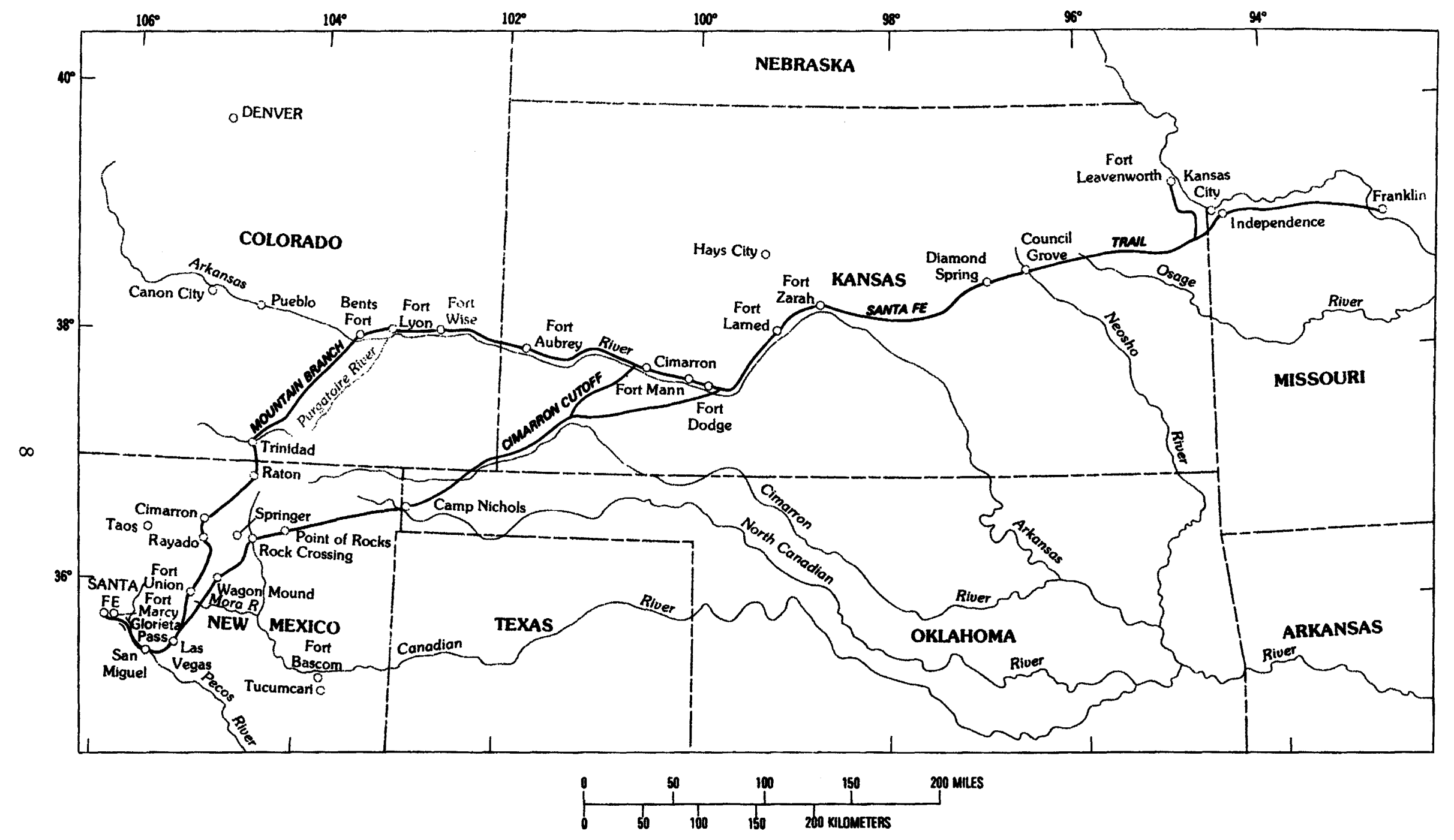

Figure 2.-Map showing routes of the Santa Fe Trail 


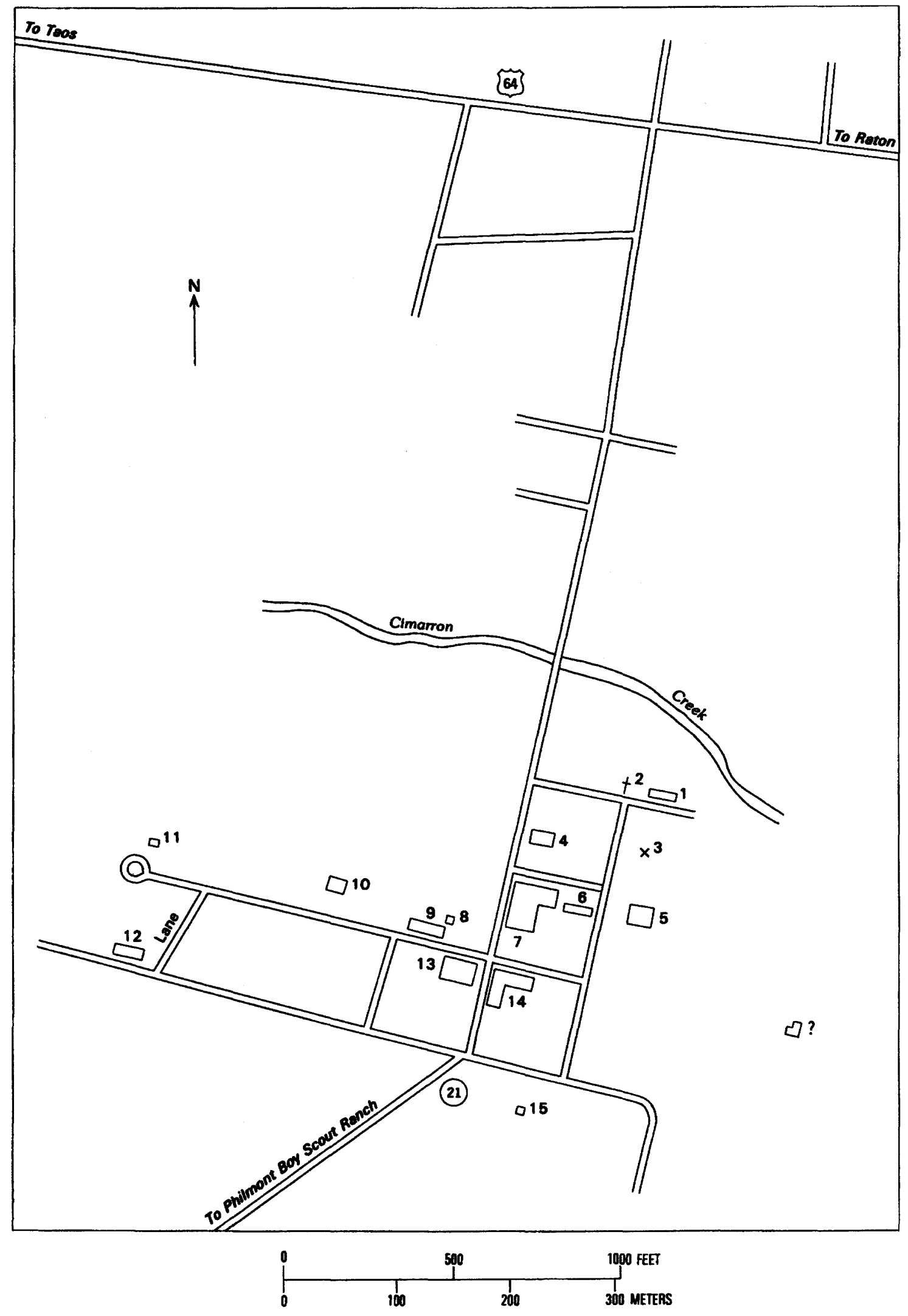

Figure 2.-Map of historic sites in the old part of Cimarron 


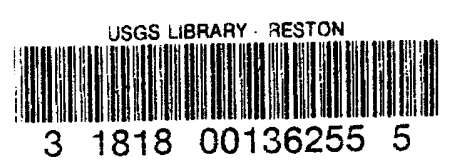

\section{ACKNOWLEDGMENTS}

I thank Frank Alpers, historian of Raton, for his help on the early history of Cimarron, on railroads, and on abandoned towns. He also reviewed the completed maps and manuscript. George R. Swain gave information about ownership and dates of operation of the railroads and reviewed the completed maps and manuscript. George Laumbach of Springer showed me details about the Santa $\mathrm{Fe}$ and other trails near Springer and located the old community of San Andres. Marilyn Mullins, editor of the Springer News Bulletin, published articles about the historical trail project, thereby enlisting the help of other local historians. She also helped locate several of the abandoned towns and later reviewed the maps and manuscript. Nancy Robertson, historian of Raton, gave much information about the abandoned towns in Colfax County and their founders. She also helped locate railroad sidings (especialiy along the Catskill line) and provided information from the Colfax County records concerning stage and railroad lines. Ruth W.Armstrong, a writer about the Chase family, located the old ranch community of Las Garzas west of Springer. Many ranchers helped immeasurably by giving access to their ranches while I was making geologic maps of the Raton and Springer 1:100,000 quadrangles. Earl $\mathrm{C}$. Kubicek gave information about the stage lines in the Raton-Springer area and reviewed the report. Marc Simmons also reviewed the final manuscript. Most of the research on books and maps was done in the Western History Department of the Denver Public Library, the Raton Library, and the Springer Library.

\section{SOURCES OF INFORMATION}

Armstrong, R. W., 1981, The Chases of Cimarron-Birth of the cattle industry in Cimarron Country 1867-1900: Albuquerque, New Mexico, New Mexico Stockman, $181 \mathrm{p}$.

Brown, J. C., 1933, Field notes on the Santa Fe Trail 1825-27, in Hulbert, A. B., ed., Southwest on the turquoise trail-the first diaries on the road to Santa Fe: Colorado Springs, The Stewart Commission of Colorado College, Denver Public Library, 301 p.

Cragin, F. W., unpub., Early far west notebooks; originals in Pioneer Museum, Colorado Springs, Colo., 28 vol. Copy at Denver Public Library, Western History Department.

Crocciola, S. F., 1952, The grant that Maxwell bought: Denver, Colo., World Press, $256 \mathrm{p}$.

Gregg, Josiah, 1845, Commerce of the prairies: New York, J. and H. G. Langley; also in Thwaites, R. G., 1905. Early western traveis. v. XIX-XX, Cleveland.

Hafen, L R., 1926. The Overiand Mail 1849-1869, promoter of settlement, precursor of railroads: Cleveland. Ohio, The Arthur H. Clark Co., 361 p.

Huning, Franz, 1973, Memoirs of "Traders on the Santa Fe Trail": Albuquerque, Caivin Horn Publishers, 153 p.

James, H. L, 1966, The Santa Fe Trail: in Taos-RatonSpanish Peaks country, 17 th Field Conference, New Mexico Geological Society, 20 p.

Lecompte, Janet. 1966, The Manco Burro Pass Massacre: New Mexico Historical Review. v. 41, no. 4. p. 305

Long, Margaret. 1947, The Smoky Hill Trail: Denver, Colo., W. H. Kistler Stationery Co., 376 p.
1954, The Santa Fe Trail: Denver, Colo., W. H. Kistler Stationery Co., 281 p.

Martin, Gene and Mary, 1972. Trail dust, a quick picture history of the Santa Fe Trail: Denver, Colo., Golden Bell Press, $55 \mathrm{p}$.

Moody, Ralph, 1967, Stagecoach west: New York, Thos. Y. Crowell Co., $341 \mathrm{p}$.

Moorhead, M. L., 1954, New Mexico's Royal road; trade and travel on the Chihuahua Trail: Norman, University of Oklahoma Press, $234 \mathrm{p}$.

Murphy, L. R. 1969, Out in God's country-a history of Colfax County, New Mexico: Springer, New Mexico, Springer Publishing Co., Inc., 115 p.

1972, Philmont, a history of New Mexico's Cimarron country: Albuquerque, University of New Mexico Press, $261 \mathrm{p}$.

1983, Lucien Bonaparte Maxwell, Napoleon of the southwest: Norman, University of Oklahoma Press, $275 \mathrm{p}$

Myrick, D. F., 1970, New Mexico's railroads-an historical survey: Golden, Colo., Colorado Railroad Museum, $197 \mathrm{p}$.

New Mexico Magazine-several issues had pertinent articles.

New Mexico Writers' Project. 1945, New Mexico, a guide to the colorful state: Albuquerque, The University of New Mexico Press, $458 \mathrm{p}$.

Pearce, T. M., ed., 1965, New Mexico place names, a geographical dictionary: Albuquerque, University of New Mexico Press, $187 \mathrm{p}$.

Pearson, J. B., 1961, Maxwell Land Grant: Norman, University of Oklahoma Press, $305 \mathrm{p}$.

Riddle, Kenyon, 1963, Records and maps of the old Santa Fe Trail: Stuart, Fla., Southeastern Printing Co., Inc., $147 \mathrm{p}$.

Swain, George, 1968, Raiiroads, towns and mining camps of the Raton region, 1860-1960: New Mexico Railroader, v. 10 , no. 4 , a map.

Taylor, M. F., 1966, Trinidad, Colorado Territory: Trinidad State Junior College, 214 p.

1971, First mail west; stagecoach lines on the Santa Fe Trail: Albuquerque, University of New Mexico Press, $253 \mathrm{p}$.

Thomas, A. B., 1935, After Coronado-Spanish exploration northeast of New Mexico, 1696-1727; documents from the archives of Spain, Mexico, and New Mexico: Norman, Okla., University of Oklahoma Press, $307 \mathrm{p}$.

U.S. Surveyor General's Office, 1889, Sectional map of Colfax and Mora Counties, New Mexico: U.S. Surveyor General.

Wheeler, 1 st Lt. G. M., 1876. Geologicai atlas projected to illustrate geographical explorations and surveys west of the 100 th meridian of longitude: U.S. Geographical Surveys west of the One Hundredth Meridian (Wheeler): Washington, U.S. Government Printing Office.

Wislizenus. F. A., 1912. A journev to the Rocky Mountains in the year 1839: St. Louis. Missouri Historical Society, $162 \mathrm{p}$.

More than 55 maps of the Raton-Springer area were examined and information extracted during the course of this study. Most of these maps were examined in the Western History department of the Denver Public Library. 

